\title{
The Joint US/French Research Partnership between the Rockdale Magnet School for Science and Technology \\ (Conyers, Georgia, USA) \\ and the Lycée de la Communication \\ (Metz, France)
}

\author{
William W Smith, Jr / Angela Hinson Quick \\ Georgia Tech / Rockdale Magnet School for Science and Technology
}

\begin{abstract}
The Rockdale Magnet School for Science and Technology is an alliance between the Georgia Institute of Technology's College of Engineering and the Rockdale County Public Schools. Immediately adjacent to Georgia Tech's French campus (Georgia Tech Lorraine) is the French high school, the Lycée de la Communication. In early 2002 and with the support of the Georgia Tech's Atlanta and French administrations, the Lycée de la Communication (in Metz, France) and Rockdale Magnet School for Science and Technology (25 miles from Georgia Tech's Atlanta campus in Conyers, Georgia USA) agreed to an experiment in which French and US students are paired to perform joint research projects. In autumn 2002, ten US students visited France to meet with their French research partners. In April 2003, French students will reciprocate and visit Georgia. Each visiting group resides in local homes and participates in the academic and home life of their host families. The organizers hope to repeat annually and expand with goals including joint and French participation in science and engineering competitions.
\end{abstract}

\section{The US School (Rockdale Magnet School for Science and Technology)}

The Rockdale Magnet School for Science and Technology (RMSST, www.rockdale.gatech.edu) was founded in 2000. This magnet high school provides a unique combination of required research classes and projects, an international research partnership, and direct liaison with college engineering personnel. Specialized AP and magnet school science, mathematics, and research classes are taught to the participating 130 magnet students by magnet school teachers, while non-magnet school classes are taken with the general population and their teachers in a 1400 student suburban US high school. Each student participates in required research classes during their $9^{\text {th }}, 10^{\text {th }}$, and $11^{\text {th }}$ grades with each student formally defining, executing, and presenting their research project in multiple fora. Research ideology is presented in $9^{\text {th }}$ grade with students' initial projects requiring an experiment with single independent and dependant variables and increasing complexity during subsequent grades. All students are required to procure mentors for their projects, execute their experiments, produce quantitative results including statistics, and provide written and oral presentations. The relationship with Georgia Tech provides access to personnel (a dedicated liaison engineering $\mathrm{PhD}$, professorial, graduate, and undergraduate assistance), facilities (i.e. nuclear, biomedical, chemical, instrumentation) typically unavailable and often unknown to traditional high school science students, and access to Georgia Tech's campus in Metz, France. Georgia Tech's interests in the magnet school include fostering more indigenous engineering student candidates. Although only beginning its third year and incorporating about 45 rising $9^{\text {th }}$ graders each year, to date and amongst other

"Proceedings of the 2003 American Society for Engineering Education Annual Conference \& Exposition Copyright (C) 2003, American Society for Engineering Education" 
honors, the school accumulated a majority of prizes in regional science and engineering fair awards, sent two students to the International Science and Engineering Fair, and produced two Siemens Westinghouse semi-finalists.

\section{The French School (Lycée de la Communication)}

The Lycée de la Communication (Lycom, www.ac-nancy-metz.fr/pres-etab/lycom) was founded in 1990 and is a 2000 student joint vocational and high school in Metz, France. Divided spatially along architectural features, the vocational school portion of Lycom features media communications specializations and support facilities including working television studios, audio and video mixing suites, electronic and traditional visual arts studios, and electronics laboratories. Again with clever architectural divisions, the high school (Lycée) portion of the school hosts the traditional three French academic tracks: arts and literature, business, and science. The relationship between the US and French schools is with the US magnet and French science track students.

\section{Connecting the US and French Schools}

Georgia Tech Lorraine (GTL, www.georgiatech-metz.fr) is the European platform for Georgia Tech, and its campus is located within visual and walking distance of the Lycom campus. Metz is midway between Paris, France and Frankfurt, Germany, and is the capital of the French Lorraine region. Located in a mountain valley in a Venice-like setting centered on islands in the Moselle River, this region was at times its own independent country and fought over repeatedly by French and German interests as is evidenced in the city's architecture and particularly the central cathedral. The European Union banking and court centers of Luxembourg are nearby. Georgia Tech Lorraine and Lycom are located on the Technopole 2000 research campus which includes several technology-oriented and international corporate and academic institutions including the French Supélec University. Metz is a cultural, economic, and geographic European center.

The nationally centralized French Ministry of Education authorities initiated a program of structured personal studies during the 2000-2001 academic year stating that all French Lycée students will experience a research component during their $11^{\text {th }}$ and $12^{\text {th }}$ grades corresponding to a six to eight week study. The central authority annually provides a set of general topics, and students are expected to identify a research topic by mid-November and to present their project by the end of the academic year.

To date, this had not been implemented in most French schools beyond poster session presentations sponsored by individual teachers. In addition, France has almost no pre-college tradition of science or technology competitions similar to US science and engineering fairs. Outside of France is an international plethora and hierarchy of competitions with many affiliated with the International Science and Engineering Fair organization (www.sciserv.org/isef).

With hopes for future interaction and prompted by international visits between Rockdale County and Metz leaders in the late 1990s, a sister-school relationship between the Metz and Rockdale high schools was declared. In December 2001, Dr. Whit Smith, Atlanta liaison between Georgia Tech and the Rockdale Magnet School, met in Metz with Michael Gegout (Director, Lycom) in a visit hosted by Dr. Francois Malassenet (Director, Georgia Tech Lorraine) to investigate

"Proceedings of the 2003 American Society for Engineering Education Annual Conference \& Exposition Copyright (C) 2003, American Society for Engineering Education" 
relationship potentials between the French and US high schools. Quickly obvious was the common research project theme. Discussions led to the decision for both schools to host research projects jointly executed by teams consisting of both US and French students. This was formalized in early 2002 with plans to experiment initially during the 2002-3 academic year by identifying and empowering pairs of (French-US) students through visits and internet resources.

The initial goal is to pair French and US students to perform research projects with hopes of submitting the results in open fora for public and competitive evaluation. To suit introducing French students to the competitive fora, the US partner students visited Lycom in November 2002 to present their research projects to prospective French partner students. French and US partner students will be identified, then the French students will visit the US school in April 2003. Following the first year, both schools' leadership will evaluate jointly and decide whether to continue.

\section{Planning and Initial Execution}

During June 2002, Dr. Smith and Mrs. Angela Quick (Director, Rockdale Magnet School) visited Michael Gegout and leadership from Lycom and Georgia Tech Lorraine to plan.

A primary constraint is scheduling driven by the academic, holiday, and vacation calendars for both schools. Although both adhere to traditional summer vacations, few other vacations overlapped in a fashion suitable to allow either French or US students to miss weeks of their required classroom time. And travel for less than a week is undesirable as the travelers do not become locally acclimated.

Students in the French school spend much of the weeks preceding the end of their academic year (mid-June) preparing for the national testing which determines much of their academic and vocational futures. This precludes exchanges during late spring as do several week-long holidays (i.e. following All Saints Day) not celebrated in the US.

Students in the US magnet school spend their first weeks of school identifying and refining their research topics. As with their later decisions regarding college major and job selection, this tends to be one of their most difficult decisions. Of particular difficulty is narrowing their research project to include an experiment with few independent and dependent variables. They then procure their resources (mentors, equipment...), execute their experimentation, and prepare reports through early January. For the remainder of their academic year, they attend various competitive and presentation fora including a three month hierarchy of science and engineering fairs and an in-house and externally reviewed formal symposium.

Preceding the autumn 2002 trip by US partner students to France, email addresses were exchanged and a publicly viewable web site was constructed illustrating the US students' research work for potential French partner student consumption. Project topics included medicine and health, physics, engineering, and environmental biology. (As of this writing and with intentions of future maintenance, the internet materials are available within www.rockdale.gatech.edu and include project details).

"Proceedings of the 2003 American Society for Engineering Education Annual Conference \& Exposition Copyright (C) 2003, American Society for Engineering Education" 
During 12-22 November 2002, ten US partner students visited Metz, were hosted in French families, and spent any time not on special tours with combinations of their host families and potential partner students. The US students formally presented their work (Microsoft PowerPoint presentations and some experimental materials) before French students and teachers. The French community provided a host of honors and activities for the US delegation including receptions and tours including historical Metz and the nearby and solemn Verdun WWI site. During this visit, leadership from the French and US schools identified mid-April as the time for French students to perform their US visit.

As of this writing, plans are established for 13 French students to visit the US school during 1323 April with activities consisting of a series of civic receptions, time in and out of school with host families and partner students, and tours paralleling those experienced by the US students during their November 2002 French visit.

\section{Successes and Challenges}

During the autumn 2002 visit by US partner students to France, the US students executed live and formal presentations before an auditorium of speakers of another language and were overwhelmed by many of their experiences. However, they proceeded in good spirits. By the end of the trip, the US and French students were behaving together in a fashion indistinguishable from that of contemporary teenagers. Financial resources for most of the trip and planning were provided by individuals and the local business community thus incurring almost no capital cost to the US school. Various press articles discussed the students' activities. US students' activities were presented almost daily via internet for consumption by their home constituency. The US students, French students, and host families appeared to enjoy their time together.

The logistics of performing the autumn 2002 trip were daunting with those and upcoming challenges including international logistics, procuring and synchronizing finances, identifying host families, travel and legal documentation for traveling, students, selecting partner students, preparing the students, language barriers, and exhaustion of available personnel resources

Although French and German language classes are available in most US high schools, the rising US Hispanic population is prompting Spanish is becoming a more popular language course than was French in the last generation. Because so few of the candidate US partner students had a working knowledge of the French language and the planners could not demand this skill for the first year students, few of the US students operationally could read or speak French preceding their autumn 2002 visit. The French students fared better with an average of six years of English courses, however, their skills were oriented more toward the written versus spoken. Progressively more involved French skills will be a component for US student selection in subsequent years.

Lycom is exploring travel and research project funding from indigenous sources similar to those listed above for the equivalent Rockdale efforts. As of this writing, several French business organizations are discussing commitment to providing finances. For both the US and French schools, developing financial sources is a need requiring continuous efforts.

"Proceedings of the 2003 American Society for Engineering Education Annual Conference \& Exposition Copyright (C) 2003, American Society for Engineering Education" 
Efforts by both the US and French were managed by a small group of dedicated champions who were operating with different constraints but similar personal enthusiasm. More acute than the chronic danger of personal "burn-out" was that key personnel might falter at critical times for any number of reasons including exhaustion. For the autumn 2002 trip, critical US personal were "dual redundant" where possible. For the US chaperones, depositing their wards into the hands of the host families was a difficult experience.

\section{Conclusion \& Future Plans}

A goal for French and US constituencies is to implement in France fora for research presentation eventually concluding in French and joint French-US participation in the International Science and Engineering Fair. In addition to the cultural exchange, both the US and French students will experience how the other experiences school and research projects.

With motivations including the appeal of international travel, candidate students for future collaboration are developing projects which incorporate the distance between the two schools. Proposed projects include computer network propagation measurements, astronomical measurements, and characterizing differences between local environmental variables.

Although the logistics and resource allocation was complex, most involved enjoyed the initial visit between the French and US students with cultural and personal growth benefits to all constituencies being great but difficult to quantitatively describe. These authors look forward to submitting a future paper illustrating additional results, modifications imposed due to experiences, and subsequent joint work.

\section{Biographies}

DR. WILLIAM W. SMITH, JR is a Senior Research Engineer in Georgia Tech's School of Electrical and Computer Engineering. In addition to classroom teaching, research, and consulting work with satellite, navigation, and instrumentation, Dr. Smith works with a variety of pre-college, undergraduate, and graduate students on programmatic and individual research and design projects.

ANGELA HINSON QUICK is the director of the Rockdale Magnet School for Science and Technology since 2000. Mrs. Quick received her undergraduate degree from Appalachian State University and her Master of Science Education from the University of South Carolina. She has 10 years of classroom science teaching and 6 years as directors of magnet high schools and pioneered the described magnet research curriculum.

"Proceedings of the 2003 American Society for Engineering Education Annual Conference \& Exposition Copyright (C) 2003, American Society for Engineering Education" 